\title{
Reforming the Tudor Dialogue: A Case Study
}

SEYMOUR BAKER HOUSE

Summary: This case study assesses the implications of rhetorical style in dialogues by Thomas Becon and his contemporary, Desiderius Erasmus. Becon imitated an Erasmian theme but rejected Erasmus's classically oriented rhetoric and the epistemology it advanced. Instead, he used the dialogue form as a vehicle for what is primarily an oral (homiletic) exhortation, which reveals a profoundly different approach to the pursuit of truth and illustrates the widening cultural gap between moderate and radical religious reformers.

Tn the summer of 1543, Thomas Becon stood at Paul's Cross in London and I publicly recanted his heretical views. After making several specific retractions, he cut up his books and renounced their contents. Becon, a priest, had recanted two years earlier for seditious preaching, after which he had adopted the disguise of lay garb to shield him from episcopal attention. In 1542 , he began to write rather than preach, publishing at least nine separate works under the pseudonym of Thomas Basil before the authorities collared him again. One of the books he abjured was his popular $A$ Christmas bankette, ${ }^{1}$ the first of seven dialogues Becon wrote between 1542 and 1562. This dialogue bears a signal resemblance to Erasmus's colloquy A Godly Feast (Convivium religiosum): similarities in theme, setting, and even the names of the characters suggest that Becon had Erasmus's text as his model. This in itself is not notable: Becon was schooled in the early 1520 s, a time when Erasmus's Colloquies were taught to those who, like Becon, studied 
Latin composition. What is remarkable is how Becon adapts the dialogue to reflect his view of the way in which laymen encounter Scripture.

Erasmus's colloquy demonstrates how the intellect is trained through dialectical inquiry, and suggests that through this training we appropriate Christian virtue. Becon works according to a profoundly different hermeneutic. His dialogue functions like a sermon in print, asserting that the power of the Word alone effects conversion. Ironically, although Becon's dialogue, appearing hand-in-hand with a vernacular Scripture, addresses the issue of lay exegesis, in fact it leaves uninstructed laymen with little means by which they might resolve the problems attendant upon reading the Bible for themselves. This article will argue that Becon's A Christmas bankette rejects the generic strengths of the dialogue, as seen in Erasmus's example, because, paradoxically for an author and an exegete, Becon favoured preaching over dialectic as a medium for our encounter with the Word.

Erasmus originally wrote his colloquies for his young Parisian pupils in the closing years of the fifteenth century. These were later collected and published (without Erasmus's blessing) in several editions in 1518. In March 1519 , Erasmus oversaw the publication of a corrected edition, and he added to this collection from time to time. By his death in 1536, over one hundred editions had been published. Additional colloquies first appeared in the 1522 edition: like the earlier works, they served as models of Latin eloquence, but these new dialogues showed "an increasing tendency to ridicule religious abuses," which doubtless led to the censure of the collection by the Sorbonne in $1526 .^{2}$

The colloquy known as A Godly Feast was among those first added in the 1522 edition. In it, nine laymen discuss various passages of Scripture, the relationship between pagan and Christian learning, and the benefits of culture. The dialogue form allowed Erasmus to present challenging observations through his characters while preserving a certain protective distance from those observations, leaving the reader to infer where his true sentiments lay. In A Godly Feast, it is just as important to pay attention to the setting and action as it is to note the unfolding argument, for frequently (and at times ironically) action underscores speech. Particularly important too is the egalitarian nature of the discussion, where many views are aired: the reader is invited to go beyond the literal sense in order to participate more fully in the issues raised.

English reformers were attracted to the popularity and authority of Erasmus and began to publish translations of his more controversial collo- 
quies as early as 1534: translations of Pietas puerilis and Funus appeared in 1534; two editions of Exequiae seraphicae were printed between 1534 and 1536; and an anonymous translation of Perigrinatio religionis ergo appeared circa 1536 with a non-Erasmian preface ridiculing monks. ${ }^{3}$ By and large these early translations preserved the wit and rhetorical appeal of their originals, and were bought by the same sophisticated readership as purchased the Latin originals - i.e., readers capable of sorting through the complex texts. Thus they never circulated as widely as their translators had hoped.

With the publication of an official English Bible in 1538, new readers joined the book-buying public, and this presented problems for those who would adapt Erasmus's complex hermeneutic to the English situation of the 1540s. Erasmian texts explicitly addressed the need for religious change but many contained material unsuited to the radical reformers in England classical allusions, an insistence on community, linguistic subtleties, a holistic approach to learning predicated on the ability to assist an inward conversion through training of the intellect and will. In addition to these problems, reformers who would adapt Erasmian texts faced the fact that the level of sophistication among the reading public had fallen as the base broadened. Particularly telling in this regard is the admission by Caius that his rendering of Erasmus's De vera theologia was "not in the ful as the authore made it, but abbreuiate ... Leuyng out many subtile thinges, made rather for great and learned diuines, then for others." ${ }^{4}$ Some reformers, such as Richard Taverner, tried to adapt Erasmus's catholic humanism to the new protestant theology in the late 1530s, but the problem of audience remained too knotty for most: after all, Erasmus's readers were learned and many were humanists; popular writers had a much less homogeneous readership. This gulf, between those who could digest Latin texts (even if only in translation) and those newly literate English readers searching for simple guidance to the Scriptures, was not easily bridged. ${ }^{5}$

In the sixteenth century, the dialogue itself was evolving away from the classical models into what one critic has called an "anti-genre." Since classical times, the dialogue had always depended not on authority but on persuasion, and had included elements of setting, characterization, and even humour in its arsenal. Commenting on the Platonic dialogue, Curley notes that "the argument itself seems to lead nowhere. An examination of the dramatic action, however, often leads to an understanding of the point of the dialogue." The complex relationship among various verbal, dramatic, and 
ludic elements in the dialogue required an especially well-trained reader to decode.

Erasmus relished multiple levels of meaning and exploited them in his Colloquies. The very fact that he began to incorporate controversial material in works originally meant for a juvenile readership is evidence of this: it is highly unlikely that the resonating "Saint Socrates, pray for us!" in A Godly Feast was meant to strike adult clerics in the same way as it might an aspiring adolescent Latinist. But it is important to note that even when multiple readerships are expected, the colloquies maintain a literary and stylistic unity in which one level functions simultaneously within another.

The varying levels at which a complex text such as an Erasmian dialogue functions led Erasmus to accept the same technique of dissimulatio he assumed Jerome had used to buttress the appeal of the classics for Christians. Even beyond Jerome lay fertile ground for cultivating the idea that concealing was part of God's plan: the Incarnation itself was a sort of allegory, requiring human elucidation. ${ }^{8}$ By posing puzzles, Erasmus was able to teach his readers not merely what to think but how to think. There was, then, an ethical dimension to reading a dialogue which encompassed the rhetorical, the exegetical, and the grammatical but transcended them all. As Allan Bloom said in the preface to his translation of Plato's Republic (1968), "[Dialogues] are meant to perform the function of a living teacher who makes his students think, who knows which ones should be led further and which ones should be kept away from mysteries. ... One must philosophize to understand them." 9 Dialogues were meant to enable readers to understand issues without recourse to mere authority.

The sixteenth-century development of an anti-genre dialogue emphasized the suasive elements over the conventional features (decorum) of the dialogue. Stemming from the publication of Agricola's De inventione dialectica in 1515, dialogues were conceived as dialectical exercises that "refused to recognize any distinction between the categories of logical analysis and the commonplaces of rhetorical tradition." 10 What this meant in practice was that writers resorted to various rhetorical devices (humour, satire, irony) more frequently than they had in the past to affect their readers in order to delight and instruct. Erasmus's Colloquies stands as the supreme example of this tendency. The efficacy of his exposition and argumentation, in short, his ability to combine dialectic with persuasion, is what gave Erasmus his great popularity, and why his style of dialogue was widely imitated. 
In A Godly Feast, Erasmus introduces us to nine characters in a peaceful rural villa who meet together on the invitation of the host to discover whether learned conversation can prove fruitful outside the cultured atmosphere of the city. This challenge, the piece's inventio (or discovery that initiates the topic), arises naturally in a conversation between the host (Eusebius) and his older friend Timothy, who argues that Socrates preferred cities to fields because only in cities could one learn. Eusebius asserts that learning is possible in a more natural setting so the two friends arrange a meal during which they will test this theory. The inventio establishes the dialogue's verisimilitude - one of the important features of Erasmus's rhetorical strategy, without which dialogue becomes the sort of scholastic dialectic he despised. ${ }^{11}$ In addition, it raises the issue of man's relation to the natural world - itself an important theme in the dialogue.

When the guests arrive, Eusebius gives them a leisurely tour of his gardens and repeatedly indicates that variety in nature and in men is something to be praised rather than deplored. ${ }^{12}$ Himself an example of the role of cultivation and education in harnessing this variety, Eusebius is a master at training the different plants and birds, even those from other climes, to thrive under his care. ${ }^{13}$ In his view, the natural world gives us an opportunity to realize God's plan. Because Scripture is the primary text of that plan, Eusebius has given Scriptural tags to prominent features of his garden. ${ }^{14} \mathrm{His}$ gatekeeper is Saint Peter, who welcomes them with trilingual Biblical inscriptions; his fountain symbolizes "that unique fountain which refreshes with its heavenly stream all those who labor and are heavy laden . . . according to the Psalmist"; and his artificial improvements ("an artistic deception") suggest man's ability to share Nature's bounty through inventiveness. ${ }^{15}$ The combined spectacle presents a feast for the eye and a lesson for the beholder - "A wonderful variety, and nothing inactive, nothing that's not doing or saying something." 16 But if Scripture is the text par excellence of God's plan, it is not the only one. Many of the lessons are drawn from classical wisdom, and their inscriptions carry the scent of Erasmus's Adages. ${ }^{17}$

Attention to the literal level of the argument is not always the only way in which the dialogue speaks a humanist message. Erasmus's rhetorical method, resting on appraisal of character, is clear in this exchange between Timothy and Eusebius concerning the relative merits of a painted garden:

Timothy: Yet it isn't fragrant.

Eusebius: But on the other hand it needs no attention. 
Timothy: It pleases only the eye.

Eusebius: True, but it does this forever.

Timothy: A picture, too, grows old.

Eusebius: Yes, but it's longer lived than we are, and age commonly adds to it a grace we lose.

Timothy: I wish you were wrong about that. ${ }^{18}$

Eusebius tailors his discussion with Timothy, well on in years and the oldest of the party, towards a conclusion he knows will be particularly persuasive for him - the question of longevity. Each speaker in this exchange speaks the truth, and only through the art of rhetoric can Eusebius put an end to differences. Note, too, that Timothy is a model learner, preferring to acknowledge Eusebius's point rather than stubbornly insist on his own preferences out of pride.

The introductory tour presents various (but hardly discordant) views on the state of Nature, its relationship to man's efforts to improve upon what he finds there, the overriding importance of Christian revelation and the mediation by Scripture between the created and the eternal. Throughout the tour we see consensus and even wisdom achieved through realistic dialectic. Also notable is the repeated emphasis on variety throughout the early part of this dialogue - a way of suggesting that consensus or even uniformity is not always attainable.

When the party moves indoors for the meal, Eusebius invites the household boy to read a passage from Proverbs before they eat, and explicitly commends this monastic practice for lay Christians, since it will give them something better to discuss than the usual "silly, bawdy stories."19 Notable are the boy's literacy and his inclusion in the scene, as well as Timothy's recommendation, which echoes the theme of training and cultivation seen in the examples of Eusebius's husbandry, that "Nothing is more advisable ... than to habituate ourselves to what is excellent." And while Scripture is offered as "seasoning" (and not the only possible seasoning, as Timothy points out), it in fact becomes another meal in itself. ${ }^{20}$

The way in which Scripture becomes metaphorical food lies at the dialogue's core. Not content merely to hear the Word, Eusebius wishes there were a theologian present to help them understand it. Timothy suggests that laymen may discuss Scripture, "provided they're cautious about passing judgment." So a round of exegetical discussions begins, undertaken cautiously by the assembled laymen, trusting Christ's promise of assistance wherever "two men are gathered together in his name." 21 Instrumental in this model are its collaborative (or dialectical) nature and the assurance that 
exegesis is indeed a proper activity for well-meaning laymen. Unquestioned is the assumption that a certain amount of discussion is necessary to understand the Word well enough for it to bear fruit in this world.

The first step in discussing a pericope on the nature of royal authority, Eusebius points out, is to discard, for the moment, the "various conjectures of commentators". ${ }^{22}$ Unencumbered by learned complexities, he is free to present what appears to him to be the "moral" sense - in other words, the sense most accessible and open. With a minimum of self-conscious erudition, he explains the figurative passages with analogies drawn from nature and preserved in classical literature. By buttressing his reading with support drawn from other Scriptural passages, Eusebius engages in a practice he later explicitly commends - comparing Scripture with Scripture - and finishes his discussion with another appeal to proper training as the best way of establishing right behaviour and of inculcating virtue. ${ }^{23}$ Throughout the exegesis, he answers questions raised by his listeners and invites their responses. In this way the discussion moves naturally from topic to topic.

Eusebius is followed by Timothy, who discusses the allegorical sense of the passage, ${ }^{24}$ and he is followed by Sophronius, who draws attention to the doctrinal issues implied by the passage. By this time, four examples of Scriptural exegesis have been presented as models, and the company pauses for its second course (which allows Eusebius to inject some barbed Biblical levity at the expense of celibates - "eunuchs for the kingdom of heaven's sake" 25 - linking them with the capons he is serving). When they resume, Eusebius praises the value of the dialectical method they are employing, whereby even mistakes afford "an opportunity of finding the answer." Erasmus's belief that public debate and eventual agreement reveal the guiding presence of the Spirit here opposes the suggestion by Luther and other protestant writers, including Becon, that clarity and understanding are produced not by public or semi-public debate but through the infusion of grace in the individual by faith. ${ }^{26}$ When his turn comes to lead the discussion, Theophilus (who knows Greek, as well as Hebrew) employs a wide variety of exegetical tools: appeal to Hebrew idioms, historicist or contextual criticism, and etymology. Any lay reader seeking guidance on the most fruitful ways of appropriating the teachings of Scripture has here the complete catalogue of methods.

The action in the dialogue affords ample opportunity for Erasmus to build on the verbal arguments presented. Using a motto on a wine cup as the inventio which initiates a new round of discussions, Eulalius (good Christian 
that he is, he has been pondering the Pauline passage "a good long while") admits that Scripture is not as easy to interpret as some might claim. In explaining his perplexity, he mentions the "tone" of the passage, which he tries to reconcile with its immediate and proximate contexts. His explanation of the conflicting interpretations encompasses Stoic teaching, ${ }^{27}$ Corinthian praxis, the proposed (opposing) solutions of Saint Ambrose and Theophylact, as well as various other Pauline passages - obviously, he is a rather learned layman. But the methods he employs are all standard exegetical methods, so the fact that he is able to do this from memory after years of pondering the problem need not startle us. What is startling is the group's response. After listening to the difficulties in the passage, they conclude that such learned questioning needs no assistance, and let the matter drop.

Two important issues emerge from the discussion of the Corinthian pericope. The first is that laymen, following established principles of exegesis, including appeal to the commentators (both Greek and Latin, of course), can legitimately and even fruitfully discuss Scriptural passages, even passages that perplexed the Fathers. The second, and more astonishing, point is that there is no resolution offered: the host simply affirms the ability of Eulalius to answer his own questions. The discussion on that pericope stops, and the action moves on. Erasmus's model of process rather than closure trusts that the very grappling with Scripture is itself rewarding.

Finally, at the close of the dialogue, the host distributes gifts emblematic of humanist themes (clocks, pens, classical and Scriptural texts), and leaves the villa to perform works of mercy - rounding out the exegetical "feast" with an affirmation of good works. Physical and spiritual nourishment have now come full circle, as the host extends the benefits of his inner conversion to others in the world beyond his table.

This much is patent from a reading of $A$ Godly Feast: insofar as it is an effective rhetorical composition, it shows that actions and dialogue must arise spontaneously, so that an appearance of reality is cultivated in which authentic philosophical and ethical questions are aired. Further, the dialogue presents a model of exegetical method through a practical discussion of actual problems in interpretation. And finally, good deeds are shown to be the fruit of learning, just as the bountiful garden is the result of cultivation.

Erasmus's more controversial views in the colloquy are less patent. Although Eusebius acknowledges that "Sacred Scripture is of course the basic authority in everything," 28 he also claims that much of the classical view on virtue is in perfect harmony with Christian teaching and even 
supersedes corrupt Christian practices, a view shared by Chrysoglottus in his criticism of the popular acceptance of ceremonies over a "more interior" means of achieving true Christian life. ${ }^{29}$ Part of Erasmus's "hidden" message pertains to the relationship between nature and man - between the visible and the invisible, the spirit and the body - as mediated by Christ and the Scriptures. ${ }^{30}$ And finally, issues of linguistic fidelity critical for accurate Scriptural exegesis, yet likewise hidden from those who do not know Hebrew or Greek, are hinted at in Eulalius's analysis of 1 Corinthians 6:12, where he explains the pericope in terms that preserve the Greek echoes of the original - something Erasmus himself presents in his Annotations. ${ }^{31}$ Erasmus's like-minded readers (whether adult or adolescent) would surely appreciate the deeper significance of these features.

Becon's A Christmas bankette displays striking similarities with Erasmus's dialogue. Guests arrive, and the host Philemon takes them on a tour of his house, pointing out inscriptions that admonish the beholders toward Christian faith and action. Two of the guests share names with characters in Erasmus's dialogue, and all of the names recall Greek or Latin church fathers, despite Becon's very English setting. Significantly, the banquet that follows is solely metaphoric: Philemon lectures on the cultivation of Christian virtue, but there is no meal. Nature is not part of the feast.

Despite many outward similarities, crucial differences remain which suggest that, although he adopted the outward form of Erasmus's dialogue, Becon ignores unique characteristics of the genre discussed earlier in connection with Erasmus's composition: discovery through dialectic and the presentation of truth through persuasive rhetoric. In place of dialectic and rhetoric - both of which build on man's natural capacities for reason and persuasion - Becon relies on Scripture's ability to imprint itself directly on the hearts of those who receive it faithfully.

From the opening scene of Becon's dialogue, his departures from the genre's conventions are clear. When the dialogue begins, the host is speaking, but he is alone, since the guests have yet to arrive and there is no servant mentioned. In this unliterary way (there is no attempt at an inventio), we learn that guests have been invited but that "before we fede our hungrye bodyes, we shoulde sustayne \& fede also our hungry soules" 32 with the word of God. Once the discussion of the inscriptions begins, naturalness is replaced by indoctrination. Leaving aside the predictability of his inscriptions ${ }^{33}$ and their at times improbable length, Philemon's passion for surrounding himself with Biblical decoration raises questions of credibility. On 
his virginals, Philemon has written, "The eye hath not sene, nor the eare hath not hearde, neyther hath it entred into the harte of man, that God hath prepared for them that loue hym," which, he says, is meant to remind us that the sound of this instrument is "vayne and fedeth [y]e eare for a lytle whyle": it is nothing compared to the "celestiall melodye" awaiting us in heaven. ${ }^{34}$ One might wonder why, with this attitude, Philemon owns the instrument at all. The incipient Puritanism for which Becon is noted also expresses itself in Philemon's views on images. Replete with examples of the written Word, the house is devoid of paintings, in stark contrast with the villa in Erasmus's dialogue. Philemon himself is an austere host, in defiance of Tudor norms of hospitality, subjecting his guests to long lecturing without offering them anything to eat or drink until he has finished.

Effective dialectic requires skilled questioning. In Erasmus's dialogue, the guests provide easily half of the conversation, and because they are as fully informed as the host, they steer it into unpredictable (and certainly unforeseen) but nonetheless fruitful areas. In Becon's work, Philemon's guests are tightly restricted: their contributions vary only slightly - from simple questions to questions of startling naïveté. ${ }^{35}$ In the more than 50 pages of dialogue, the conversation is relentlessly driven by Philemon, as he exposes his guests to the dishes he has prepared. Their few queries are always anticipated by the host, and his answers, without exception, remain unchalenged. In no case does any guest provide reasoning or material that furthers he discussion or uncovers something previously hidden. Quite literally, they tre his audience.

The lack of verisimilitude generates confusion and contradiction. While ve might accept that Englishmen bear Greek or Latinate names, the point of uch exotic nomenclature, which suggests grounding in patristic learning or amiliarity with Biblical sources, is lost when we realize that the bearers of hese names are illiterate, even in English. Both Theophilus and Eusebius ave to ask what is written on various objects. ${ }^{36}$ In each case, Philemon upplies the reading. Beyond this, even the most basic Christian tenets come $s$ surprises to them. Eusebius has never heard of original sin; both Eusebius nd Theophilus have to ask, "What moued God to be so beneficiall vnto vs, eyng we had offen so greuously, \& were than by no meanes able to pacify lis wrath with ony good work?"; and Christopher, being informed (for the :irst time?) by Philemon that "ye are not able of your selues to recouer youre nnocency, that ye lost by Adam," cries out in near-comic bewilderment, "Alas, what is now to be done?"37 And lest we explain this naïveté as part 
of Becon's polemical message (i.e., that in truth they had not been living in a Christian country but rather in a country that had drifted away from Christianity), we note that they are familiar at times with conventional Biblical stories, while both Theophilus and Christopher link knowledge of Christ and his laws with obedience to the king and the maintenance of good household order in a most conventional (suspiciously official) manner. ${ }^{38}$

These inconsistencies, troubling as they are, are lessened if we imagine for a moment that Becon's readers were men - householders - similar to his characters, and that literary stylistics were of little consequence where matters of faith and governance were concerned. In this perspective, Philemon's catechetical feast suggests that Becon's readers were meant to see themselves first as recipients then as repeaters of the lessons in $A$ Christmas bankette. Evidence to support this reading of the dialogue is plentiful. After the tour of inscriptions is over, Philemon shows his guests two "great tables" (i.e., tablets) hanging in his dining room and explains that one is a table of the ten commandments "which teacheth vs what we ought to do, \& what to exchew" and that the other is a table depicting

the offyces of al degrees and estates. It teacheth vs what we owe to oure mooste noble Prince, to oure parentes, $\&$ to all superioures. In this table euery man from the hyghest degre to the lowest may learne his offyce \& duety. Therfore are these two tables redde euery daye openlye in my house, my wife, \& chyldren, with all my seruantes beyng called thereunto. ... . If any of my houshold transgresse any percel of gods law, he is brought streightwaye to these tables, and by them is his faut declared vnto hym. So that hereby he taketh an occasion to amende his lyfe, \& to be the more circumspecte $\&$ ware, that he falleth not agayne into the synne afterward. This is the order of my house. ${ }^{39}$

So much for rhetoric: relationships can be schematized and displayed, and transgressions can be rectified, by mere reference to the scheme. After the revelation that Philemon's household functions ideally owing to his good government and the presence of the tables, in one of the longest contributions by a guest in the whole dialogue, Theophilus praises the benefits that will accrue to all and sundry when "all householders ... take an example of you. Would God that many seyng this your acte, would in lyke maner folow it in euery condicion, garnyshyng theyr houses with holy scriptures, \& trayning theyr lyues accordynge to the same. Oh what a florysshynge realme than shoulde we haue?"40 Such a top-down model of good order ignores true dialectic, and places the host (householder) in the role of mediator between God and man, or, in this case, between Scripture and the household. In fact, householder becomes preacher. 
Thus far in the dialogue the guests have been treated only to an exposition of the inscriptions, which, it seems, are sufficient in themselves to instill good order in the household. The various husbandmen have professed themselves convinced that the example of Philemon's house will serve equally well - unchanged - in their own. Gone is the art of adapting the message to the listener, and gone is the acknowledgment of variety.

Yet the guests cannot effect a change in their households, as Philemon has done in his, without first experiencing a change in themselves. Having already displayed a profound ignorance of Christian teaching, they must somehow become like Philemon himself if they are to aid in the spiritual transformation of their households. Their education and conversion occur in the second half of the dialogue, where they are treated to four lectures on the Christian faith, structured so as to expose their dependence on God and to elicit their thankful repentance. If Erasmus's dialogue emphasizes change through adaptation and long practice, Becon's stresses near-instantaneous conversion.

What follows is a standard assembly of Scriptural passages showing man's inability to achieve salvation without faith. The first dish sets the tone: "Cursed is the erth in theyr worke. It shall brynge forth vnto thee thornes \& brymbles." 41 This strong theme of contemptus mundi runs throughout the rest of the dialogue, emphasizing our depravity and the debasement of nature as consequences of the Fall. Instead of an eloquent garden with its promise that we can improve upon the created world through our own efforts, in Becon we find a "vale of misery." 42

Given the sola Scriptura hermeneutic and the disparagement of reason, it is no surprise that Philemon's exegesis consists solely in citing Scripture to support his assertions. Some figurative language is explained, and some doctors are cited, ${ }^{43}$ but Philemon's main technique is overwhelming repetition. To support a typical point on election by God as the sole path to salvation, Philemon heaps up nine Scriptural passages, each keyed (however loosely) to the theme of works, justification, or choosing. ${ }^{44}$ Questions provoke new proof-texts: when Theophilus asks, "But how shall we know, whan we truly repent on such maner, that it prouoketh God to be mercyfull to vs?," Philemon launches into another lengthy catena of passages. ${ }^{45}$

Faced with the austerity of this dialogue, where were Becon's readers to turn? The dialogue's exegetical method - citing Scripture to elucidate Scripture - is of limited use, since none of Philemon's guests (and presumably few of Becon's lay contemporaries) could move as easily through the 
Scriptures as does the host. Philemon's explanations also lack the linguistic basis on which Tyndale and other well-schooled reformers grounded their doctrinal observations. And while the dialogue form generally presents readers with various characters (or viewpoints) with whom they could identify, Becon's readers are in a more complex situation than usual. They clearly cannot identify too closely with the guests, since the guests are illiterate but the dialogue was printed. To identify with the host would be to claim the host's remarkable Scriptural and patristic learning, as seems incongruous for the purchaser of a cheap and quite unliterary dialogue. The most likely scenario has already been mentioned - that the readers of Becon's dialogue were themselves householders whose responsibility toward their household impelled them to seek some form of rudimentary catechetical aid at a time of considerable theological uncertainty. The closest examples to hand for Becon, when preparing such an aid, were his sermons.

That Becon's dialogue is in fact a sermon is supported by several features. Most importantly, his catenae of Scriptural passages are invariably triggered by the most simple verbal suggestions. Moreover, Philemon's argument is abbreviated to the point of absurdity: no attempt is made to shape a convincing line of reasoning around the quotes. Take, for example, the list of twelve uninterrupted Scriptural and patristic passages offered in support of the doctrine of original sin. If we omit the Scriptural material itself, what remains is quite stark: "We reade in the fourth boke of Esdras the third chap. on this wyse ..."; "Also Ose the Prophete sayeth ..."; "sayth S. Jerome, vpon this texte ..."; "But I wyll reherse to you more scriptures ..."; "Christ also sayeth ... "; "Agayne ... "; "Also in an other place ... "; "S. Paule also sayeth ...."; "Agayne ...."; "In another place also he sayth "; "Therefore Dauid confesseth that ..."; "And saynte Paule affyrmeth playnelye that...." 46 There is no argument, as one might expect in a dialogue, despite the presence of Philemon's unearned "Therefore" before a quote from the Psalms and his suggestion that the final Pauline quote "affyrmeth" the others. The point of the catena becomes clear as Philemon asks, "What say ye nowe my frendes, do ye not nowe at the laste perceyue that the synne of Adam hath condemned vs all, so that his synne is our synne," to which Christopher, speaking for the guests, acknowledges that they both see it and believe it. ${ }^{47}$ The Word, unadorned and baldly stated, has done its job through the preacher.

Other features confirm a profound rhetorical and conceptual distance between speaker (Philemon) and audience (guests/readers). Philemon fre- 
quently addresses his guests as an undifferentiated group standing apart from himself - "do ye not nowe at the last perceyue"; "we haue learned what ye are"; "Therefore must ye confesse yourselues to be that in dede, which ye are, that is, very synners . . "48 — and emphasizes his directing control over the group, as they move from one "dish" to the next. In conventionally oratorical style, at the close of the dialogue Philemon says he will "gather togyther in few wordes that which hytherto I haue dispersed in many, that they may the more easly remayne in your brest," 49 further emphasizing the teaching function of his lecture. In addition, Becon's heavy reliance on patristic sermons rather than theological works supports the homiletic nature of his approach.

In Becon's work, reason and dialectic, rhetoric and persuasion, are compromised in favour of an approach based on the power of the Word, presented through the sermon, to effect change of life. The immediacy of preaching a sermon imposes a different structure than does the writing of a dialogue. This structuring is chronological, with emotion succeeding emotion until the required intensity (and commitment) is reached. In the first half of the dialogue, the need for order is established. In the second half, the means of attaining that order are presented. Thus, in the second half, Philemon establishes the general condition of humanity, in which natural variety is subsumed by universal depravity; this means that only through Christ will our deliverance come, not through our own efforts. He goes on to tell his guests that belief in Christ and the subsequent repentance such belief entails comprise the only way. To underscore the conversion that genuine belief carries with it, Becon then presents the following emotional crescendo:

Eusebius: This is the moost pleasaunt dysshe that euer I tasted.

Theophilus: These thynges that you haue spoken vnto vs are so confortable that me thynke, I am nowe enflamed \& more set on fyre than euer I was before.

Christopher: As I maye vnfaynedly reporte vnto you the affect of my herte, verely syns that ye declared to vs the goodnes of God the father toward vs thorow Jesus christ I haue felte in my herte such an earnest fayth \& burnynge loue towarde God and his worde, that me thynke a thousande fyres coulde not plucke me away from the loue of hym. I begynne nowe vtterlye to contemne, despyse, reiecte, cast awaye, \& sette at nought al the pleasures of this world, wherein I haue so greatlye reioyced in tymes past. . . 50

Once the guests have been drawn to this point, it remains only to inform them how to gauge whether their newfound faith is true. Thus the fourth "dish" 
discusses the works that are the hallmark of sincere repentance and amendment of life.

The hortatory nature of the dialogue, evident throughout, completes the impression that Becon's dialogue is a sermon adapted for print. By casting it as a dialogue, Becon acknowledges the prominence of the genre, which encompassed not only the Erasmian model but also the traditional form of Christian catechesis. Becon's hasty switch from sermon to print is borne out by biographical details: after falling afoul of the authorities, he recanted his views publicly in Norwich in 1541, and, as he put it, "changed the form of teaching the people from preaching to writing." 51 What this means is now clear. Instead of speaking his message, he had it printed, making only a modicum of changes to accommodate the new medium.

For students of early modern print culture, Becon's adaptation of an oral work to a printed medium is instructive - paralleling as it does a similar movement from orality to literacy in the popular church, as well as in English society at large. When Becon wrote $A$ Christmas bankette, English Scriptures were just becoming available to the larger reading public, a fact Philemon notes. ${ }^{52}$ Works were pouring off the presses with advice on how to deal with the new accessibility of the Word. Yet Becon's dialogue affords no instruction on how Scripture is to be read. His laymen, with the exception of the host, are illiterate. Without Philemon's preaching, they would lack even a rudimentary apprehension of Christian truth. What Becon has given them instead of a model of exegesis is a volume of proof-texts and a plan for household catechesis, centred on the paterfamilias - a plan which, if followed, would guarantee not only correct Christian doctrine but godly domestic management.

These two dialogues, one advancing the Christian humanist message through dialectic tempered by rhetoric, the other rejecting dialectical inquiry in favour of the Word's unaided power to establish true conversion, present diametrically opposed approaches to the question of lay exegesis of Scripture so pressing in late Henrician England. ${ }^{53}$ Both attempt to establish a basis for conversion stemming from an encounter with the Word. Erasmus's method relies heavily on education, linguistic ability, and long training. Becon might well have felt these were luxuries England could ill afford, given the pace of change he had witnessed in the decade before he began writing. By reforming his dialogue, Becon suggests that Erasmus's model is unnecessarily complex for the needs of emerging readers of Scripture, as well as theologically flawed. In its place, he offers a dialogue showing that exposure 
to the Word through the sermon converts, and enables its hearers to effect like conversion in others. In this view, there is no need to adopt a pre-Christian past, with its trust in reason and its assumption of a neutral or benign Nature; nor is there a need to imitate its rhetoric, its textual models, or its methods. By changing a familiar Erasmian colloquy into a sermon, Becon establishes a new model of order - domestic, civil, and cosmic - based on Scripture alone. The readings and texts of the past have become obsolete.

\section{Mount Angel Seminary}

\section{Notes}

1. No. 1714 in A Short-Title Catalogue of Books Printed in England, Scotland, and Ireland and of English Books Printed Abroad, 1475-1640, first comp. by A. W. Pollard and G. R. Redgrave, 2nd ed., rev. and enl., begun by W. A. Jackson and F. S. Ferguson, completed by Katharine F. Pantzer, 3 vols. (London: Bibliographical Society, 1976-91). Becon's work ran to three editions in 1542: STC nos. 1713, 1714, and 1715.

2. E. J. Devereux, Renaissance English Translations of Erasmus: A Bibliography to 1700 (Toronto: University of Toronto Press, 1983), p. 50.

3. Ibid., pp. 67-69.

4. Ibid., p. 4. In his dedication of his collected works to Archbishop Parker, Becon also professes the common touch: "[T]herefore in all my sermons and writings I have not attempted matters of high knowledge and far removed from the common sense and capacity of the people" (The Works of Thomas Becon, ed. John Ayre for the Parker Society, 3 vols. [Cambridge: Cambridge University Press, 1843-44], I: 27). Of course, Becon cites Psalm 131 as his precedent in humility.

5. See John Yost, "Taverner's Use of Erasmus and the Protestantization of English Humanism," Renaissance Quarterly, 23 (1970), pp. 266-76. An example of a successful contemporary English dialogue (on literary if not polemical grounds) is Thomas More's Dialogue concerning heresies, but there are few others. Given the popularity of the form during the English Reformation, More's signal success proves the difficulty of the task. More's Utopia is included among the five genuine Tudor dialogues (out of more than 230 written) by Roger Deakins ("The Tudor Prose Dialogue: Genre and Anti-Genre," Studies in English Literature, 20 [1980], pp. 5-23), although he does not consider it a "true" dialogue along classical lines.

6. Deakins, p. 18.

7. Augustine F. Curley, Augustine's Critique of Skepticism: A Study of Contra Academicos (New York: Peter Lang, 1966), p. 32.

8. James D. Tracy, "Erasmus Among the Postmodernists: Dissimulation Bonae Literae, and Docta Pietas Revisited," in Hilmar Pabel, ed., Erasmus's Vision of the Church, Sixteenth Century Essays and Studies XXXIII (Kirksville, MO: Sixteenth Century Journal, 1995), pp. 10-11. Biblical models of dissimulatio were plentiful but none more convincing than the repeated admonitions of Jesus to conceal his divine nature. See Manfred Hoffmann, Rhetoric and Theology: The Hermeneutic of Erasmus (Toronto: University of Toronto Press, 1994), pp. 66 and 123. 
9. Quoted in Curley, p. 32.

10. Deakins, p. 7.

11. In the dialogue itself, Eusebius decries the lack of rhetoric (or "feeling") in the dialectic of Scotus (A Godly Feast, The Colloquies of Erasmus, trans. Craig Thompson [Chicago: University of Chicago Press, 1965], p. 65; hereafter referred to as Godly Feast). For the role of "feeling" in Erasmian writing, including the nature of the ludic in dialogue, see Walter Gordon, Humanist Play and Belief: The Seriocomic Art of Desiderius Erasmus (Toronto: University of Toronto Press, 1990).

12. E.g., "The same scent doesn't please everyone" (Godly Feast, p. 49), "Every man to his tastes," and "One garden wasn't enough to hold all kinds of plants" (p. 52). Phrases stressing the variety and multiplicity of nature include "varied spectacle," "many species," and "a wonderful variety" (p. 53).

13. Godly Feast, p. 55.

14. This is emblematic of Erasmus's hermeneutic: Nature resembles divine wisdom because we are led to reason from the visible to the invisible, and the Word mediates between these realms. See Hoffmann, passim. Dialogue was thought to be an outer form of the interior reasoning process itself, and therefore essential to any process of discovery. See Stephen A. Tyler, "Ode to Dialog on the Occasion of the Un-for-seen," in The Interpretation of Dialogue, ed. Tullio Maranhão (Chicago: University of Chicago Press, 1990), pp. 298-99.

15. Godly Feast, pp. 51-52.

16. Ibid., p. 53.

17. With the "seasoning" provided by a good appetite in A Godly Feast (p. 49), cf. "Hunger is the best sauce" in Adages, Collected Works of Erasmus, vol. 34, trans. and annotated R. A. B. Mynors (Toronto: University of Toronto Press, 1992), p. 34.

18. Godly Feast, pp. 52-53.

19. Ibid., p. 56.

20. Ibid., p. 57.

21. Ibid.

22. Ibid.

23. Ibid., p. 58. There are, of course, deliberate echoes of Erasmus's Antibarbari here.

24. In Erasmus's view, allegory bridges the gulf between letter and spirit, the visible and invisible, the material and the spiritual (Hoffmann, p. 11).

25. Godly Feast, p. 60.

26. Ibid. For Erasmus and the public consensus against the private and essentially unverifiable exegetical method advanced by Luther, see Marjorie O'Rourke Boyle, Rhetoric and Reform: Erasmus' Civil Dispute with Luther (Cambridge, MA: Harvard University Press, 1983), pp. 133-34.

27. E.g., "Nothing is useful unless likewise honorable" (Godly Feast, p. 63).

28. Ibid., p. 65.

29. Ibid., pp. 68-69 
30. Hoffmann, p. 254.

31. Erika Rummel, Erasmus' Annotations on the New Testament: From Philologist to Theologian, Erasmus Studies 8 (Toronto: University of Toronto Press, 1986), p. 101.

32. Christmas bankette, sig. A5.

33. E.g., on the door Philemon has inscribed "the sayeng of Christ, "I am the dore. By me yf ony man entreth in, he shall be safe, and shall go in \& oute, \& shall fynde pasture." And on the window is written "Christes sayeng in the Gospell of S. John 'I am the lyght of the worlde"' (Christmas bankette, sigs. A6-A7).

34 Ibid., sig. B4.

35. E.g., the astonishingly naïve remark of Eusebius: "Me thynketh that thoughe [Adam] offended, yet his offence should not turne to our damnacion, seynge we were not then borne" (Christmas Bankette, sig. C2 ${ }^{\mathrm{v}}$ ).

36. Ibid., sigs. $\mathrm{A} 6^{\mathrm{v}}-\mathrm{A} 7 \mathrm{v}$.

37. Ibid., sigs. $\mathrm{C}^{\mathrm{v}}$, $\mathrm{D} 6^{\mathrm{v}}, \mathrm{C} 8$.

38. Ibid., sigs. A $8^{\mathrm{v}}, \mathrm{B} 6-6^{\mathrm{v}}$.

39. Ibid., sig. B5.

40. Ibid., sig. B5 $5^{\mathrm{v}}$. Other guests use language suggesting that the head of the household is, in fact, the household's pastor, an identification that furthers the quasi-clerical role Becon imagines for his adult male readers. See Christmas bankette, sigs. B6, B6V .

41. Ibid., sig. $\mathrm{C1}^{\mathrm{v}}$ (cf. Gen. 3:17-18).

42. Ibid., sig. C2.

43. E.g., "by thorns and brambles are meant sin and wickedness" and "I wyl read vnto you the mynde of the famous Doctour Origen, concernyng this matter" or "And that ye maye knowe that I wraste not the scriptures, I wyl read vnto you the sayeng of S. Austen ... " (Ibid., sigs. $\left.\mathrm{C} 2^{\mathrm{v}}, \mathrm{D} 4^{\mathrm{v}}-\mathrm{D} 5\right)$.

44. Ibid., sigs. D4-4v'.

45. Ibid., sig. E8.

46. Ibid., sigs. C3-3․ (Note: on C3 the names of Philemon and Theophilus have been wrongly transposed by the typesetter.)

47. Ibid., sigs. $\mathrm{C} 3^{\vee}-4$.

48. Ibid., sigs. $\mathrm{C} 3^{\mathrm{v}}-4, \mathrm{C} 6, \mathrm{C} 8^{\mathrm{v}}$.

49. Ibid., sig. G6.

50. Ibid., sigs. F4 $-\mathrm{F} 5$.

51. Derek Bailey, Thomas Becon and the Reformation of the Church in England (Edinburgh: Boyd, 1952), p. 18.

52. Christmas bankette, sig. G3v. But the proclamation of 1541 states that while English subjects may read the Bible, "no lay subjects reading the same should presume to take upon themselves any common disputation, argument, or exposition of the mysteries therein contained..." The 1543 Act for Advancement of True Religion severely curtailed lay Bible 
reading. See P. Hughes and J. Larkin, eds., Tudor Royal Proclamations, 3 vols. (New Haven: Yale University Press, 1964-69), I: 297.

53. The conflict between the old and the new is further reflected, although less clearly, in the economics of the works. While Erasmus intended his scholarship to advance the literacy even of the plowmen, the price, in combination with his choice of Latin as the language of composition, suggests that his works were aimed primarily at the traditional book-buying class: his dialogue was part of a larger quarto collection, costing perhaps one shilling or more. It is significant that when Erasmus's controversial colloquies were issued in English, they appeared not in quarto volumes, as was common on the continent, but rather in cheaper octavo editions to widen their circulation. Becon's Christmas bankette also first appeared in octavo, at an unbound price of around 3d. For book prices, see Francis Johnson, "Notes on English Retail Book-prices, 1550-1640," The Library, 5th series, 5.2 (1950), pp. 83-113; for the evolution of contemporary print culture, see Seymour House, "Literature, Drama, and Politics," in The Reign of Henry VIII, ed. Diarmaid MacCulloch (New York: St. Martin's, 1995), pp. 181-202. 